\title{
¿LITERATURA SIN ESTADO?: SOBRE LAS APORÍAS DEL RÉGIMEN ESTÉTICO EN LA MODERNIDAD CAPITALISTA
}

\author{
LITERATURE WITHOUT A STATE?: ON THE APORIAS \\ OF THE AESTHETIC REGIME WITHIN CAPITALIST MODERNITY
}

\author{
Antonio GÓMEZ LÓPEZ-QUIÑONES \\ Dartmouth College \\ antonio.gomez@dartmouth.edu
}

\begin{abstract}
Resumen: Este ensayo explica cómo la esfera estética es el efecto de un proceso de diferenciación que el proyecto de la modernidad impone progresivamente sobre diversas áreas de toda la vida y producción social, tanto práctica como teórica. De este proceso de especialización y parcialización emana también la literatura como un ámbito de valores específicos y experiencias propias. Un aspecto fundamental de este entramado es el Estado en tanto que sostén material y garante simbólico del quehacer y poder políticos. A partir de esta distinción, este artículo muestra que los intentos por lanzar puentes entre estética/literatura y política han naufragado en esa inercia centrífuga que divide y encierra ambos campos en su propia lógica interna y en su propia institucionalidad. Para una larga tradición filosófica, la salida a este nudo gordiano pasa por la abolición de ambos regímenes sociales (política y estética), esto es, la cancelación del Estado y la Literatura.
\end{abstract}

Palabras clave: Literatura, Política, Estado, Estética, Modernidad, Marxismo

Abstract: This essay explains how the aesthetic sphere was historically produced by a process of differentiation that Modernity progressively develops in several areas of social life, both practical and theoretical. Out of this process of specialization and fragmentation, literature precisely emerges as one sphere with its own specific values and possible experiences. A critical element of this process of specialization and fragmentation is also the State, which works as the material structure and the ultimate symbolic guarantor of any political power and activity. Based on this constitutive and historical distinction between aesthetics and politics, this essay suggests that attempts at throwing bridges between these two fields have systematically failed due to the centrifugal inertia that encloses these fields within their own internal rationales and institutionalities. In order to cut this Gordian knot, what is required (according to a long philosophical tradition) is the abolition of both social regimes (the political and the aesthetic), that is, the cancelation of the State and Literature.

Keywords: Literature, Politics, State, Aesthetics, Modernity, Marxism 


\section{$\mathbf{O}$} gros, Colosos, Ex Machina

El título que encabeza este dossier, «Literatura y Estado», sugiere un fuerte desequilibrio entre dos entidades con connotaciones muy dispares. Es inevitable sentir la fragilidad líquida de la Literatura (incluso si la escribimos con mayúscula) ante la marmórea consistencia de lo que Octavio Paz llamase, en feliz expresión, el «ogro filantrópico» (1979: 12). No es casualidad que la edición que Seix-Barral publicase de este último ensayo en 1979 lleva en su portada otra célebre encarnación de la desmesura del 'cuerpo' estatal, El Coloso de Goya. Si Paz alude al Estado mexicano que nace de la Revolución y cuyos tentáculos el P.R.I. ramifica como un ingente organigrama de prebendas y acumulación, Goya retrata (así lo aseguran sus intérpretes) la amenaza aplastante del Estado en mitad de un proceso bélico, la Guerra de Independencia (Castro Oury, 19; Glendinning, 105) ${ }^{1}$. La figuración visual del Estado como gigante, titán o Ser superior, a mitad de camino entre lo monstruoso y lo sublime, cuenta con una larga tradición. El frontispicio diseñado por Abraham Bosse para el Leviathan (1651) de Hobbes ha ejercido un notable influjo en los debates modernos sobre el tema. Este monarca hercúleo, compuesto por centenares de figuras humanas de espaldas al lector, blande su espada y báculo sobre el paisaje, evidenciando las promesas y el temor que provoca un ente político sin par². Un último ejemplo: Giovanni Botero, oponente acérrimo de Machiavelli, publica en 1589 Della ragion de Stato (La razón de Estado) ${ }^{3}$. En la tapa de este tratado, un animal alado de grandes proporciones (no identificable con ningún ave específica) se posa sobre un cetro en llamas mientras toca con el pico los rallos del sol. El lema de la banda que adorna la escena reza así: «Semper Eadem» («Siempre igual»).

Todos estos casos (desde el ogro filantrópico de Paz al Fénix de Botero, pasando por el Cuerpo de cuerpos de Hobbes y el torso descomunal de Goya) demuestran que la imaginación moderna requiere del monstruo o del cíclope (o de una combinación de ambos) para plasmar el Estado en una

\footnotetext{
${ }^{1}$ El estado español y el estado moderno por antonomasia en el siglo XVIII, el francés, son un tema recurrente en la obra de un pintor con una gran intuición política. Cuadros como Los fusilamientos del Tres de Mayo y muchas de las piezas que integran Los desastres de la guerra dramatizan las contradicciones de un Estado moderno e ilustrado que solo ilumina (literal y metafóricamente) su propia violencia maquinal y ciega. Lienzos como El Dos de Mayo en Madrid ilustran, al igual que otros muchos momentos en Los desastres de la guerra, que las fuerzas que se oponen a dicha violencia no le merecen a Goya mejor opinión. Jack Schwartzwald interpreta el primer cuadro citado como una suerte de crítica romántica de cierto geometrismo racionalista que desencadena el terror en nombre de la emancipación en los modernos Estadosnación (22).

${ }^{2}$ Para disipar cualquier posible ambigüedad, un versículo del Libro de Job (41:24) aparece en la parte superior de este icónico frontispicio: «Non est potestas Super Terram quae Comparetur ei».

${ }^{3}$ El jesuita Botero reprocha a Machiavelli una ausencia general de conciencia moral en la serie de consejos pragmáticos que da al príncipe, así como un excesivo énfasis en cuestiones técnicas para la manipulación efectiva del poder. De hecho, Botero menciona como causas para el fracaso de un Estado «la envidia, la rivalidad, la discordia, la ambición entre nobles, la frivolidad» (6). Entre los valores que alaba en un gobernante, Botero nombra «esas virtudes que se dedican al beneficio de otros, la humanidad, la cortesía, la misericordia» (16). El «amor» y la «reputación» son los fines ulteriores a los que debería además estar encaminadas todas esas virtudes (17). Este es, en términos generales, el tenor del ensayo de Botero, que aspira a ciertas cualidades éticas y a un reconocimiento mutuo y respetuoso (aunque también asimétrico) entre gobernantes y gobernados.
} 
imagen. Incluso en la versión salvífica y redentora de éste (Botero y Hobbes) hay algo terrible e innombrable. Tan espeluznante e intenso es el Estado que, cuando intentamos captarlo en una estampa, ilustradores e intelectuales han tenido que concebir animales intimidatorios y humanos animalizados, fuera de toda proporción y verosimilitud. No es extraño que Nietzsche, al preguntarse en Así habló Zaratustra « ¿Un estado! ¿Qué es eso?», conteste lo siguiente: «Estado es el nombre que se da al más frío de todos los monstruos fríos. Es frío incluso cuando miente; y esta es la mentira que se desliza de su boca: "Yo, el Estado, soy el Pueblo"» $(44)^{4}$. Es revelador que un pensador tan atento a los imaginarios colectivos de su época captase perfectamente la centralidad del vocabulario de lo monstruoso para describir el Estado. Con igual perspicacia se acerca Nietzsche, el filólogo clásico empedernido, a las etimologías latinas y griegas. Quizá por eso merezca la pena recordar que «monstruo» viene de la forma latina «monstrum»y esta a su vez del verbo «monere», que significa avisar o advertir. El «monstrum» funciona como una advertencia o señal que los dioses envían a los humanos mediante un prodigio o suceso sobrenatural ${ }^{5}$. El Estado es un monstruo porque se trata (antes incluso que del poder mismo) de la advertencia del poder. Este no tiene límites o sus límites son ignotos: el advenimiento de unas prerrogativas y facultades no necesariamente religiosas, pero sí transhumanas, no equiparables con la dimensión caduca de la cotidianeidad. En definitiva, el Estado es el monstruo acechante e imposible de contrarrestar, el que nos alerta de su inaudita contundencia antes (o después) de mostrarse.

Junto a estos personajes de complexión exorbitada, el Estado ha inspirado una serie de narrativas basadas en la máquina, en la metáfora de lo maquinal, el sistema automatizado de engranajes sobre el que nadie, en el fondo, ejercita su voluntad. Esta es la máquina sin agente conductor. El propio Octavio Paz explica, en el texto ya citado, que «el Estado moderno es una máquina pero es una máquina que se reproduce sin cesar» (1979: 85). A lo que añade de inmediato: «La sociedad civil ha desaparecido casi enteramente: fuera del Estado no hay nada ni nadie [...] El Estado es el ser y la excepción, la irregularidad y aún la simple individualidad son formas del mal, es decir, de la nada» (85). En la exposición de Paz se percibe un tono angustiado y apocalíptico, que nos remite a una genealogía de textos distópicos. En esta tradición destacan, por ejemplo, El tacón de acero (1908) de Jack London, «La máquina para» (1909) de E.M. Foster, Nosotros (1921) de Yevgeny Zamyatin, El juicio (1925) de Franz Kafka, Un mundo feliz (1932) de Aldous Huxley, Anthem (1938) de Ayn Rand, 1984 (1949) de George Orwell, «El informe de la minoría» (1956) de Philip K. Dick, El cuento de la criada (1985) de Margaret Atwood y La conjura contra América (2004) de Philip Roth ${ }^{6}$. No todos estos autores responden a las mismas preferencias ideológicas ni mucho menos a encrucijadas históricas parecidas. En cualquier caso, a todos los conecta un hilo común: la ansiedad ante un Estado injerente que,

\footnotetext{
${ }^{4}$ Para darle uniformidad lingüística al conjunto, todos los originales en inglés han sido traducidos al español. Estas traducciones son responsabilidad del autor del ensayo.

${ }^{5}$ Verbos como demostrar o mostrar tiene precisamente su origen en la forma latina monstro, monstrare.

${ }^{6}$ En el ámbito hispano, existe una rica historia de textos futuristas, utópico-distópicos, que desde la biología o incluso la teología imaginan Estados futuros donde la perfección humana ha sido realizada. En México, al calor de la Revolución de 1910, se publican varias novelas que capitalizan el impulso transformador del alzamiento popular de Villa en el norte y Zapata en el sur. Para este tema, recomiendo el trabajo de mi colega Jorge Quintana-Navarrete.
} 
12 Tropelías. Revista de Teoría de la Literatura y Literatura Comparada, número extraordinario 4 (2018) Antonio Gómez López-Quiñones

mediante la tecnología y la burocracia, despersonaliza a los ciudadanos, los organiza como otra especie zoológica más e hiper-planifica su existencia hasta en los ámbitos más privados.

Como se ha afirmado anteriormente, estas ficciones surgen de lealtades políticas diversas (el derechismo libertario de Rand, el socialismo democrático de Orwell, el anti-bolchevismo de Zamyatin o el progresismo secular - típicamente anglosajón - de Philip Roth). Ahora bien, la fuente filosófica más influyente de crítica anti-estatal, de la que beben además estos autores directa o indirectamente, es un determinado liberalismo. Este liberalismo defiende el supuesto quehacer orgánico y participativo de los mercados o la sociedad civil frente a la «opresiva maquinaria estatal» (Fawcett, 231; Gottlieb, 67). La prevención contra el Estado y sus innatas propensiones disruptivas y totalizantes surge claramente en dos nombres fundamentales de esta escuela de pensamiento, Friedrich Hayek y Milton Friedman. El primero encabeza el segundo capítulo de El camino a la servidumbre, titulado «La gran utopía», con la siguiente cita de Hölderlin: «Lo que siempre ha transformado el Estado en un infierno en la tierra ha sido precisamente que el hombre ha tratado de convertirlo en el cielo» (24). El economista de Chicago abre su libro Por qué el gobierno es el problema con una lista de ámbitos en los que el entrometimiento del Estado no solo no soluciona nada sino que enquista las dificultades: «educación», «crimen y falta de ley», «sin hogar», «valores familiares», «sector inmobiliario», «asistencia médica», «sistema financiero», «congestión del tráfico», «aeropuertos»y otros asuntos «misceláneos» (2001: 2-6). Friedman concluye que el «estado hace tantas cosas que no debiera, que no hace bien lo que tiene que hacer» $(2001: 6)^{7}$.

Las palabras de Octavio Paz adquieren ahora un sentido más definido. Estamos ante un imaginario relativamente reciente que desconfía y reniega del Estado porque su funcionamiento es descrito como el de una maquinaria insensible a los matices, una apisonadora de la creativa heterogeneidad humana, un proliferante armazón de dispositivos automatizados. El Estado sería el autómata per excellence, el aparato auto-regulado que, en el mejor de los casos, solo nos devuelve una versión pálida e inanimada de la existencia social y subjetiva. Su presencia es robótica, impersonal, autística y, sobre todo, supra-abarcadora. La presencia del Estado es apabullante y, como en todo sistema que se retro-alimenta, nadie conoce ni domina ya sus últimos resortes: el Estado ha cobrado vida propia justamente cuando se nos muestra como una rutina muerta. El liberalismo confiere el más potente arsenal argumentativo a esta visión del Estado como sistema infernal que tiraniza a su base constituyente. Este no es sin embargo el único arsenal. Por dentro y fuera del liberal-capitalismo discurre un afluente anarquista que complementa todo lo anteriormente dicho con una dimensión antropológica.

Tanto el anarquismo de derechas (anarco-capitalismo) como el de izquierdas (anarcocomunismo) difieren en muchas facetas, pero comparten dos pilares. En primer lugar, para ambos el «Estado político no constituye una asociación voluntaria y descansa de hecho en la coerción, siendo

\footnotetext{
${ }^{7}$ En su famoso Libre para elegir (que fue también un programa de televisión de diez capítulos), Friedman equipara capitalismo y libertad, y critica además los resabios socialistas en muchos gobiernos occidentales tras la caída del Muro de Berlín (1990: ix-x). Concluye Friedman que «la marea ha cambiado, aunque dista mucho de ser la marea que tanto se necesita para asegurar el brillante futuro de la libertad humana» (1990: xi). Este diluvio de libertad lo traerían los mercados y destruiría los Estados actuales para dejarlos en estructuras «estrechamente limitadas» (1990: 4).
} 
además destructivo o limitador de las libertades individuales» (Sartwell, 17). El propio Sartwell asevera que para el anarquismo «el Estado político nunca está justificado [...], el poder estatal no tiene ninguna justificación moral»(17). Todo el espectro libertario participa en alguna medida de este apriorismo. En segundo lugar, el Estado provoca una distorsión antropológica, desfigurando violentamente ciertas inclinaciones humanas. El Estado no solo conlleva una agresión política, sino además un error epistemológico pues desconoce o desdeña hechos fundacionales de nuestra constitución ético-existencial. Para la vertiente conservadora, esta suerte de ADN radica en lo que una de sus voces de referencia, Josiah Warren, teorizó como un individualismo tout court, una inapelable y absoluta individualidad, alérgica a cualquier tipo de cooperativismo, propiedad colectiva y configuración social normativa: «al igual que la electricidad parece ser el principio vital del individuo, esta individualidad parece igualmente permear todo y ser el principio vital de la sociedad» (57). Warren pone predeciblemente el Estado o el «gobierno» en lo alto del oneroso pódium del despotismo que aniquila dicha individualidad (74-77).

Para la escuela comunista del anarquismo, la tergiversación del Estado es igualmente dura, aunque de distinta naturaleza. En el anarco-colectivismo o el anarco-sindicalismo, la propiedad privada es justamente el pecado de origen (una idea extraída de Rousseau) ${ }^{8}$, y la asociación/socialización voluntaria entre sujetos supone la condición de posibilidad de su propio desarrollo y libertad. Un régimen de propiedad privada bajo la tutela del Estado desencadena una dinámica destructora de acumulación competitiva (Moss, 124) ${ }^{9}$. El Estado interrumpe esta predisposición innata (mutualismo, cooperación, horizontalidad, uso comunal, emancipación de las costumbres), haciendo las veces de gran bastidor coactivo para la expropiación de riqueza, para la atomización de las personas en tanto que meros soportes de derechos jurídico-abstractos, y para la gestión elitista de lo publico (perfecto envés complementario de lo privado). En resumen, para las dos grandes ramas del anarquismo (la que mira al mercado-Capital con simpatía y la que lo percibe con espanto), el Estado se presenta como una pesada armadura que se sobreimpone sobre unas dinámicas humanas inherentes que, de ser dejadas a su libre albedrío, tienden a una armónica auto-regulación de la convivencia.

\footnotetext{
${ }^{8}$ Mucho antes de Rousseau, encontramos una larga tradición pagana y religiosa en la que sin duda el autor francés encontró inspiración. Antonio Escohotado, en su primer volumen de Los enemigos del comercio, estudia una multiplicidad de textos antiguos, primitivos y medievales que estigmatizan la propiedad privada, el intercambio mercantil y la acumulación de riqueza como semillas de degradación moral y social.

${ }^{9}$ Rousseau es uno de los autores que, fuertemente influenciado por la conquista de América y el contacto con los habitantes nativos, desarrolla la idea del buen salvaje. En su Discurso sobre economía política, Rousseau establece que "es demasiado tarde para desencajarnos de nosotros mismos una vez que el yo humano, concentrado en nuestros corazones, se ha involucrado activamente en esas despreciables preocupaciones que eliminan la virtud y maquillan la vida de las almas bellas" (21). El contrato social que salvaguarda esas almas bellas es ése en el que se da «la total alienación de cada asociado con todos sus derechos en la totalidad de la comunidad [...]. Además, ya que la alienación se realiza sin reservas, la unión es tan perfecta [que] ningún asociado tiene nada que reclamar» (50). Como bien explica Paul McLaughlin, Rousseau es un autor contradictorio (hay varios «Rousseau»). El que más inspira a los anarquistas no reside en el defensor del republicanismo, sino el iconoclasta que lucha pasionalmente por la libertad y el bienestar común, y que además critica las sociedades modernas incipientemente capitalistas del egoísmo e individualismo antropológicos (106).
} 


\section{Cultura, Estética, Literatura}

¿Qué sentido tiene la anterior recapitulación sobre el Estado para el tema de este dossier? Su relevancia estriba en que, al emparejar mediante una conjunción copulativa Estado y Literatura, el segundo término adquiere todas las connotaciones que no corresponden al primero. Existe un archivo de textos e imágenes sobre el Estado tan firme (manifestación suprema de ingeniería social, con sus paquidérmicas dosis de paranoia administrativa y autarquía potestativa) que, ipso facto y casi como efecto de una disimilitud dicotómica, el sustantivo «literatura» queda ungido por un manto de fragilidad y precariedad. Frente a la sombra del mayor artilugio político jamás inventado, la literatura se impregna de una textura delicada en una escala mucho menor, de una densidad quebradiza, más cercana a la fibra interior (psicológico-espiritual o afectivo-somática) de un sujeto emplazado en el día a día, en su complejo e inasible desenvolvimiento mundano ${ }^{10}$. Hay una sugerencia en este par de un abrasivo artefacto panóptico de gestión (el Estado) que amenaza constantemente con cooptar una realidad histórica en fuga (la Literatura). El primero sería el nivel macro (uniformador e integrador) mientras que la segunda registraría a un nivel micro capas de vida corporal y mental altamente sutiles y contingentes. El encapsulamiento de la Literatura por parte del Estado implicaría, por ende, un acto de sujeción y casación. Ese material indomeñable que compone la literatura, que la construye desde dentro en instancias puntuales e impronosticables, se solidificaría y estandarizaría. Donde el Estado circunscribe el discurrir zigzagueante e incierto de la Literatura, esta última muta en una pieza o función más del primero.

Admito que el párrafo anterior plantea exclusivamente un recorrido fenomenológico por algunas formas de conciencia que la relación Estado-Literatura ha adoptado a lo largo del siglo XX. Este paisaje síquico, que en mi opinión goza aún de una envidiable salud, tiene un correspondiente historiográfico bastante firme. No nos encontramos (no solo) ante un escenario de impresiones mentales, sino también ante una cronología de instituciones y discursos que han erigido la Literatura como un evento antinómico (en relación al Estado) y endémico a un humus trans- o para-institucional. Este evento está sujeto (como todo fenómeno eventual) a unas pautas propias que ninguna herramienta de gerencia gubernamental puede forzar en una dirección fija ${ }^{11}$. Hay varias maneras de sacar a la superficie esta estirpe de pensamiento meta-literario, y aquí vamos tan solo a ensayar brevemente las más significativas, tres en total, comenzando por la óptica panorámica más amplia y terminando por

\footnotetext{
${ }^{10}$ De alguna manera, este argumento se podría plantear trayendo a colación la primera de las propuestas narrativas de Italo Calvino para el (entonces) próximo milenio, la levedad (3-35). En vez de considerarla un rasgo de un tipo de literatura, la levedad podría considerarse, frente a la pesadez y gravedad del Estado, un elemento constitutivo de toda literatura, en la que «no esperamos encontrar nada más que aquello que podemos traer con nosotros» (35).

${ }^{11}$ Utilizo la palabra «evento» en un sentido técnico y no como un acontecimiento más o menos intenso de proporciones considerables (una catástrofe natural o una ceremonia social importante). Como explica Slavoj Žižek, el evento tiene un origen religioso y contiene un elemento milagroso, aunque sea en una versión secularizada (4). Una definición inicial podría ser esta: «un evento es por lo tanto el efecto que parece exceder sus causas - y el espacio de un evento es el que abre una brecha o un intervalo que separa el efecto de sus causas» (Žižek 5). Desde una perspectiva literaria, una novela o poesía surge como un efecto creativo de un origen que no se puede estipular del todo. En contra (por ejemplo) de la razón de Estado y sus procedimientos de dominación, la Literatura escaparía en tanto que suceso eventual, imprevisto y no repetible mecánicamente. Ningún Estado, no importa cuán abrasivo sea, puede normalizar causalmente el milagro de (al menos) cierta literatura.
} 
la más circunscrita. El primer marco de comprensión en el que analizar cómo la fina arena de la literatura se escapa (valga la metáfora) de entre los abruptos dedos del Estado es, sin duda, el concepto de cultura.

Como explica Terry Eagleton, esta locución «pertenece a un léxico pre-industrial» en el que denotaba el desarrollo integral y el cultivo armónico de la personalidad (2000: 10). Dicho léxico emana en los albores de la Ilustración para suplementar no solo el vocablo civilización sino también su perdida progresiva de valor. El lenguaje que Eagleton selecciona para ilustrar este antagonismo es muy revelador: «la civilización era abstracta, alienada, fragmentada, mecanística, utilitaria [...]; la cultura era holística, orgánica, sensual, autotélica y recolectiva» (2000: 11). Una vez que a este substrato se le suma el abono romántico-humanístico, germina una idea de cultura sobrecargada semánticamente: espacio inventivo, recreativo, cohesivo y plural, esto es, material pero también locus privilegiado del florecimiento incalculable del espíritu (Löwy, 79-83). Evidentemente, esta concepción de la cultura, de la que emana su bifurcación etnográfica y luego (paleo-)científica, plantea un horizonte de actos, vivencias y objetos muy vasto. La literatura (especialmente la poesía) forma parte de dicho horizonte. Allá donde el Estado incita golpes de urbanización e industrialización, allá donde también blande el estandarte de sacudidas civilizatorias (léase destructivo-dominadoras) en las colonias y en los inmensos márgenes de las metrópolis imperiales, la Cultura resiste como reserva de formas alternativas de vida imaginativa y corporal. La Literatura es una de esas líneas de defensa frente a lo que Löwy nombra «la marea (la marejada) de la modernidad»: «el espíritu calculador (Rechnenhaftigkeit), el desencanto del mundo (Entzauberung der Welt), la razón instrumental (Zweckrationalität)» (18).

Un segundo contexto, bastante más restringido que el de la cultura, es la estética. La transición entre ambas resulta lógica porque «la cultura como forma de vida es una versión estetizada de la sociedad, encontrando en ella la unidad, inmediatez sensual y libertad [...] que asociamos al artefacto estético» (Eagleton, 2000: 25; énfasis añadido). ¿Por qué asocia Eagleton la cultura a una versión estetizada de la sociedad y esta última a una libertad coincidente consigo misma, auto-referencial? Voy a explicar esta cuestión con argumentos extraídos de varias fuentes emparentadas entre sí, Kant, Schiller, Marcuse y Rancière. No es secreto que el primero afianza en su tercera Crítica los términos y tendencias motrices de casi toda la discusión moderna sobre estética. Una vez que se teoriza la razón pura (epistemológica) como el funcionamiento espontáneo (no electivo ni volitivo) del esquematismo categorial apriorístico (Pippin, 161 y 167), y una vez que se sanciona la razón práctica (moral) como la exigencia autónoma del universalizable y formalista imperativo categórico, Kant emprende un tercer proyecto filosófico presidido por la libertad, en el que razón pura y práctica queden además engarzadas. De este engarzamiento no me puedo ocupar aquí ${ }^{12}$; del rol de la libertad en la estética sí.

\footnotetext{
${ }^{12}$ En su libro sobre la tragedia griega y la filosofía alemana, Joshua Billings explica que «el juicio estético aparece por lo tanto como una manera de mediación entre los dominios de la razón práctica y pura, Vernunft y Verstand» porque el sujeto ve en la belleza una muestra de lo moralmente bueno, contemplando lo racional en lo empírico (78). Esta es una forma de unidad porque hay contacto con lo empírico y también con lo moral, sin que por ello dicho sujeto se someta al esquematismo de las formas o al imperativo categórico. En el juicio estético, las categorías del Entendimiento, las formas que perciben los sentidos y las ideas de la Razón se acoplan armónicamente.
} 

Antonio Gómez López-Quiñones

Kant afirma que el «gusto es la facultad de juzgar un objeto [...] mediante una satisfacción o insatisfacción enteramente desinteresadas» (10). Las sensaciones que el sujeto percibe a través de esta facultad no provienen de cualidades intrínsecas al objeto (como sostenía el empirista Burke) sino de «ninguna otra cosa que el estado de mente en el libre juego de la Imaginación y del Entendimiento» (16), esto es, de las formas de la primera y las categorías del segundo. En resumen, en la experiencia estética logramos la conciencia de «una mutua armonía de unos poderes cognitivos con otros» (17). Esta no es una simple operación epistemológica ni moral, sino un juicio inmediato, contemplativo y desinteresado. El placer derivado de lo bello, y Kant distingue léxicamente entre diversos tipos de goces, deviene de la apreciación de las formas y no de la satisfacción corporal (por ejemplo) del apetito sexual o alimenticio. Lo que distingue a uno del otro es que en la estética rige una «propositividad sin propósito» (26) mientras en otras experiencias sensoriales opera un fin exterior preexistente y su satisfacción. Aquí está la semilla de una libertad subjetiva no sometida a la causalidad del esquematismo apriorístico (de la que el sujeto ni siquiera es consciente), ni al peso de la Ley de leyes (el imperativo categórico). En la primera transacción el sujeto dice adiós al noumeno pero da la bienvenida a un conocimiento viable de la verdad, en concreto, a sus condiciones de posibilidad. En la segunda transacción, se sacrifica toda consideración sobre lo empírico, pero se obtiene un tipo de certeza sobre la consecución del bien. En la Crítica del juicio, nos adentramos (más allá de cualquier transacción) en un territorio gratuito, sin finalidades ulteriores. En la estética, no hay teleología sino tautología, un tipo de placer inútil, impráctico y auto-contenido, en definitiva, el disfrute de la libertad frente al imperio de la necesidad o la obligación ética.

La tercera pata del proyecto kantiano tiene consecuencias políticas de primer orden. Mientras que en el Estado hobbesiano y en toda la tradición contractualista, los sujetos renuncian a muchas de sus potestades y/o derechos (naturales o no) para ceder su uso monopólico a una entidad central, la estética propicia algo muy distinto. No es necesaria la ley escrita (la letra de la ley) y el respaldo coercitivo del Estado para su complimiento pues, gracias el «tipo de subjetividad universal» de la experiencia estética, se entreteje otro tipo de comunidad socio-política:

[...] cuando, para Kant, nos encontramos a nosotros mismos concurriendo espontáneamente en un juicio estético, capaces de coincidir en que un cierto fenómeno es sublime o bello, estamos ejercitando una forma muy preciada de intersubjetividad, estableciéndonos a nosotros mismos como una comunidad de sujetos afectivos o sujetos de las emociones, conectados por una rápida respuesta de nuestras compartidas capacidades (Eagleton, 1990: 75).

La tensión entre Literatura y Estado se manifiesta en estas reflexiones de Eagleton con toda claridad. Si el Estado nos rodea como una exterioridad ya dada, un producto alienado y alienante que invade nuestra autonomía con la desgarradora heteronomía de una institución reificada, la estética (la Literatura) obra una suerte de milagro político, la cuadratura del círculo que tanto preocupó a Machiavelli, Montesquieu, Robespierre o Lenin. Libertad y necesidad se impregnan mutuamente hasta su plena indistinción; fuerza (externa) y aquiescencia (interior) confluyen; norma y hecho coinciden. En el instante de la vivencia estética surge una modalidad de cuerpo místico aunque laico y secular, cohesionado por una vivencia individual pero compartida. Las subjetividades concuerdan libremente. 
Cada una ejercita su libertad (estética), y en dicho acto personal e intransferible se incorpora (sin pretenderlo y sin imposición foránea) a una comunidad de sensibilidades y afectos. Por eso la estética se torna en un terreno de especulación política tan fecunda. Su fuerza no pasa por una jurisprudencia codificada al modo napoleónico, tampoco por un decálogo de mores y costumbres, y menos aún por la administración del Estado. El tipo de sociabilidad libre al que la estética nos predispone sincroniza a unos sujetos con otros sin presión exógena alguna. A ella llegamos sin perseguirlo, aunados por una sensibilidad apreciativa común. En definitiva, en la experiencia estética somos libres y podemos serlo todos además coordinadamente. Parafraseando el clásico ensayo de Robert Nozick, Anarquía, estado, utopía (1974), la estética es la paradójica utopía del Estado anárquico, donde orden y contención social se corresponden perfectamente con nuestra libertad.

El documento filosófico donde queda reflejada paradigmáticamente esta tensión entre Estética (Literatura) y Estado es Cartas sobre la educación estética del hombre. Merece la pena detenernos un instante en este conjunto de misivas porque, en ellas, Schiller aborda el quid de la cuestión que aquí vengo desarrollando. Schiller critica, como es bien sabido, la sobrecarga racionalista de la Ilustración y la inutilidad sangrienta de la Revolución Francesa. También formula su famosa teoría del «impulso formal» y del «impulso sensible», así como de la capacidad liberadora de la contemplación de la belleza. En su última carta, Schiller comenta las consecuencias políticas de estos postulados:

Si en el estado dinámico de los derechos, el hombre encuentra al hombre como fuerza y restringe así su actividad, si en el estado ético de las obligaciones se opone a él con la majestad de la ley y encadena por ende su voluntad [...], en el estado estético el hombre necesita aparecer solo como forma, confrontarse solo como un objeto de libre juego. Garantizar la libertad a través de la libertad es la ley fundamental de este reino (Schiller, 1795: 137).

En los párrafos finales del volumen, Schiller culmina la idea: en este «Estado estético», «Estado de la Belleza en la Apariencia», «Iglesia pura» o «República pura», «todo, [...] incluso el mero instrumento sirviente, es un ciudadano libre con los mismos derechos que el más noble» (140). En este punto, no importa tanto que Schiller admita que este Estado no exista aún en ningún lugar, como que sí existe «como necesidad en cada alma pulcramente afinada» (140). Para salvar esta distancia entre potencialidad y factualidad, o para generalizar ese Estado Estético que solo se da por el momento en «unos pocos círculos selectos» (140), no se requiere de un alzamiento jacobino, de un partido de vanguardia, del descabezamiento del Estado y de un nuevo andamio gubernamental. Tan solo se necesita una amplia pedagogía que, en cada individuo, despierte su predisposición congénita a vivir estética y, por tanto, libremente. En el seno de esa invisible coreografía social de los espíritus que se deleitan en la belleza como forma esencial de coexistencia, el Estado es redundante. Lo que este hace a sangre y fuego, como fuerza bruta o imposición epidérmica, la Estética lo realiza a través y desde cada voluntad individual, movilizando los resortes nucleares que constituyen y mueven al sujeto desde lo más medular. Schiller no preconiza una anti-política, el refugio de la belleza ante el vendaval de la historia. Al contrario, su estética es una Política de políticas, una ultra-política de máximos que vuelve superfluas las demás intervenciones públicas. La estética actúa como un dinamizador meta-político en ese subsuelo psíquico del que emana una comunidad equitativa y justa. 
No debiéramos reducir la relevancia de estos argumentos al supuesto desasosiego démodé entre la intelligentsia ilustrada. La antinomia Estado-Estética (Literatura) no es solo el producto de diatribas (post)iluministas sobre la razón y sus otros (el cuerpo, los sentidos, los sentimientos, el deleite, etcétera). Críticos como Paul Guyer y Brian O’Connor han rastreado, por ejemplo, el fuerte influjo de Schiller en el pensador marxista que más sintonía mostró con el último movimiento contestatario del siglo XX (Mayo del 68), Herbert Marcuse. En un texto publicado en 1969, Un ensayo sobre la liberación, el pensador berlinés pone en su punto de mira, por un lado, la razón tecnocrática y corporativa del productivismo capitalista y, por otro, dos patrones de Estado que le producen un idéntico rechazo. Marcuse ataca «el burocrático Estado del bienestar» (4) y el «comunismo burocrático centralizado» (89). La solución a la catástrofe que, según Marcuse, ha provocado esta deriva histórica no se salda «simplemente con estándares más altos de vida» que nivelen los desequilibrios entre grupos demográficos (15). Tampoco se supera con los utensilios tradicionales de una Izquierda demasiado cercana a aquello mismo que desea combatir: «esa red completa de partidos, comités y grupos de presión» (63). Tal y como promovía Schiller, la solución se encuentra en lo que Marcuse re-enuncia como «el Principio Estético como Forma del Principio de Realidad» (90). Más específicamente, la estética alumbra el camino de "la forma posible de una sociedad libre» (25). Este «aesthetic ethos» (24) suministra el modelo de una praxis donde la imaginación no se supedita a los cálculos economicistas y privilegia la cooperación lúdica, placentera y experimental. La crítica marcusiana (y esto nos sirve de adelanto de las posiciones de Rancière) ataca la sublimación burguesa de la estética en productos artísticos o «la segregación de la estética frente lo real» (32), esto es, la reducción de la Forma estética a la producción técnico-pictórica o técnico-literaria (43), su trivialización en tanto que «realidad secundaria»(42). Para Marcuse una Estética integral implica su re-socialización: el contenido de la Forma estética es lo social, y debe actuar sobre y en este contenido ${ }^{13}$. La Forma estética no es un sub-entorno especializado de objetos, sino «una de las necesidades del ser, universal más allá de cualquier variedad subjetiva de gustos y afinidades» (32). Hay en Marcuse, sin duda, un grado de ontologización y biologización de la Estética porque ésta opera (o debiera operar al menos) a un nivel constitutivo. Los seres humanos somos y nos reproducimos estéticamente, dando forma a nuestra convivencia social. Solo disponemos de un motor de transformación libre, la estética.

Como veremos de inmediato, esta reprobación del Estado (occidental-democrático y soviéticocomunista) en aras de una libertad estética y de una estética libre se traduce en lo siguiente: la desaparición de uno arrastra (como en el efecto dominó) la abolición del otro. El fin del Estado es tan solo la otra cara de la expiación de la estética, y viceversa. Con el mismo ademán que damos el adiós al Estado nos despedimos también de la estética (esto es, nos despedimos tanto de ese sub-medio prescriptivo de creación de piezas artísticas, como de la reflexión teórica sobre dichas piezas). Antes de adentrarnos de lleno en este asunto, es útil reparar un segundo en la contribución de Jacques

\footnotetext{
${ }^{13}$ Marcuse expresa esta idea de manera muy contundente cuando explica que su propuesta de liberación se plasmaría en un "Aufhebung del arte: el final de la segregación de la estética de lo real, pero también el final de la unificación comercial del negocio y la belleza, explotación y placer” (32). En otras palabras, Marcuse plantea dos objetivos: des-especialización y des-comercialización de la experiencia estética.
} 
Rancière a este diálogo. En gran medida, Rancière adopta el mismo punto de partida de Jürgen Habermas en El discurso filosófico de la Modernidad: "para finales del siglo XVIII, la ciencia, la moralidad y el arte estaban institucionalmente diferenciados como campos de actividad en los que las cuestiones de verdad, justicia y gusto se elaboraron autónomamente» (2000: 19). En la estela de Max Weber y al igual que su colega frankfurtiano Axel Honneth ${ }^{14}$, Habermas ubica en el centro de la Modernidad una máxima gradualmente diferenciadora entre prácticas y subjetividades. Esta diferenciación, como afirma Perry Anderson, termina por hacer insostenible un horizonte racional y comunicativo aglutinante (38). Cada sub-universo social se enrosca en su propia lógica e institucionalidad, quedando hipostasiado e inmune a cualquier dialéctica mediadora de emancipación total. Este es, para Habermas, el paradójico talón de Aquiles de la Modernidad: la libertad y el progreso que impulsa la autonomía de los diversos círculos sociales (arte, política, religión, ciencia, moral) se ven severamente cercenados por esa misma autonomía y ruptura mutua.

En un conciso texto integrado en La política de la estética, que lleva por título «Regímenes artísticos y las deficiencias de la noción de Modernidad», Rancière defiende que dicha noción

[...] parece haber sido deliberadamente inventada para prevenir un claro entendimiento de la transformación del arte y su relación con otras esferas de la experiencia colectiva. La confusión introducida por esta noción tiene, me parece, dos formas principales. Ambas [...] dependen de la contradicción constitutiva del régimen estético de las artes, que convierte el arte en una forma autónoma de vida (Rancière, 2000: 26).

Rancière se refiere, en primer lugar, a la autonomía del arte anti-imitativo que exaspera el mundo soberano de las formas y, en segundo, al ya mencionado proyecto de realización de esas formas estéticas - «región de libre juego y apariencia» (27) - en la objetividad histórica. Ambas vías fracasan respectivamente en el callejón sin salida de la denominada «crisis del arte» (26) y en el recurrente desencuentro entre vanguardia política y vanguardia estética. Si la primera disfruta de una conciencia (conectada al partido) que interpreta los signos del cambio histórico, la segunda nos brinda (à la Schiller) un adelanto de esa vida-libre-por-llegar en las formas puras de la literatura, música o escultura. A la primera (el partido) Rancière la llama «archi-política» y a la segunda (la subjetividad estética universal) «meta-política» (30). Las erróneas presuposiciones que se dan en el seno del arte moderno no son sino el producto de un «régimen estético» (un régimen propio y distinto) que delimita inclusiones y exclusiones, así como particiones normativas internas entre géneros y modos de representación y, sobre todo, de no-representación (22-23). Una vez que lo estético y lo político quedan desconectados (galvanizados por raisons d'être inconmensurables), la «noción de modernidad» tan solo expresa para Rancière los diversos vericuetos en los que se ha intentado infructuosamente suturar esa disociación.

\footnotetext{
${ }^{14}$ Dada la fragmentación de la vida social moderna, Alex Honneth se pregunta si «es viable hoy [...] una teoría crítica de la sociedad» (xi), es decir, si la Teoría Crítica que Horkheimer desarrolla en su célebre y homónimo ensayo sirve hoy para confrontar los problemas del presente (x). La misma idea hegeliana de «reconocimiento» resulta problemática en un mundo laboral basado en la exclusión (xvii-xviii). En general, Honneth conecta sus argumentos con esa tradición frankfurtiana según la cual «las patologías de la sociedad moderna» y su «decisivo desorden [Störung]» se achacan a la «autonomía alcanzada por esas orientaciones en el pensamiento y la acción conectadas con los objetivos de la dominación instrumental de la naturaleza» (xix).
} 

Antonio Gómez López-Quiñones

A diferencia de Marcuse, que aún creía en la estética como gran política, Rancière señala el impasse entre dos opciones imposibles: o bien la estética se repliega en las formas puras y consolida la distancia con todo lo que la rodea, o bien se proyecta sobre el mundo social de la producción para producir un salto cualitativo ultra- o alter-revolucionario (el ludismo estético como conciencia primigenia de praxis transformativa). Tras el giro posmoderno, ni la estética es hoy en día ese cobijo privilegiado donde experimentar la otredad libre del sometimiento social (Adorno ha muerto, podríamos decir parafraseando a Nietzsche), ni tampoco es esa conciencia que, bajo una nueva educación sentimental, nos propulsaría a la tierra prometida de la autodeterminación. Las formas estéticas se han integrado en el abrasivo mercado del capitalismo tardío. Esta saturación mercantil de la estética contradice los anhelos, por ejemplo, de Bertolt Brecht (el extrañamiento como intervención política) o Walter Benjamin (la politización comunista de la estética contra la estetización fascista de la política) (1968: 241-42)). El capitalismo post-fordista (hiper-consumista y mega-mercadotécnico) ha deparado algo bastante distinto: la economización de la estética, su comercialización ${ }^{15}$. La estética es hoy el eje más efectivo y eficaz de un capitalismo que empapa lo simbólico, los deseos, las imágenes, la identidad, la imaginación y los órganos perceptivos.

\section{Nostalgia, Resignación, Dialéctica}

Las tesis de Rancière me ayudan a dar una vuelta de tuerca al análisis de la relación entre Estado y Literatura. Desde el siglo XVIII la estética se configura como un régimen de la estructura social moderna, que tendencialmente evoluciona hacia su diferenciación. Pudiera dar la impresión de que «régimen» equivale a lo que Foucault llama en diversos momentos epistemes, formaciones discursivas o tecnologías del poder. Esta impresión es errónea. Estos dos discípulos de Althusser marchan en direcciones opuestas. Mientras Foucault teoriza el poder mediante su disgregación en múltiples nódulos conceptuales e institucionales, Rancière propone (al menos en el texto citado) que la Modernidad implica la acumulación de poder en uno de los regímenes que la conforman, la política. Aparquemos la cuestión sobre qué significa «política» aquí y pospongamos también el hecho de que ambos autores no utilizan «poder» en el mismo sentido ni con el mismo énfasis ${ }^{16}$. Lo relevante ahora es que Rancière subraya la histórica trágica de todos esos conatos por dar el salto del régimen estético al de la política. Como dos carriles que se curvan y aproximan sin llegar nunca a tocarse, la estética ha

\footnotetext{
${ }^{15}$ Uno de los autores que, de manera más ambiciosa ha desarrollado este tema, es Gilles Lipovestky. En el volumen que co-firmase con Jean Serroy, La estetización del mundo, explica como la estética funciona como la punta de lanza del capitalismo de consumo. En este capitalismo, la dimensión estética de los productos adquiere una importancia inaudita. Frente al «valor de uso» e incluso el «valor de cambio», aparece (no al margen de los dos anteriores sino entreverado con ellos), una suerte de valor estético. En mitad del «capitalismo artístico», dicho valor estético se convierte en el verdadero estímulo del consumo y de sus ritmos. En definitiva, el diseño o estilo de la mercancía, así como los valores que a dicho diseño adjudicamos, actúan como verdadero reclamo para su adquisición y para el expresivismo acumulativo del sujeto.

${ }^{16}$ Uno de los peligros que Bruno Bosteels señala en cierta tradición de pensamiento estético es «un radicalismo que pivota en su propio vacío, un pensamiento del puro "hay" arte y política sin una inscripción en un lugar y tiempo específicos y de acuerdo a modos históricos concretos [...] un cierto izquierdismo especulativo de nuestra época» (164). Es importante la advertencia de Bosteels porque nos recuerda que tenemos que contextualizar geo-históricamente las formas de política y estética que se van afianzando, sin esperar a que llegue la Política o la Estética (o su simple afirmación filosófica) como gestos definitivos y del todo salvíficos.
} 
pretendido ser y hacer política... sin éxito. Una y otra vez, se ha visto re-asimilada a los confines de su propio régimen. En paralelo, otros agentes con otros medios y con metas diferentes han ensayado prácticas e intervenciones propiamente políticas (partidos, sindicatos, grupos armados, gerencia estatal, etcétera).

Puesto que la Modernidad delimita campos en los que se des-agrega lo previamente amalgamado (moral, estética, religión, ciencia...), y puesto que la Modernidad política tiene en su epicentro el problema del Estado (su conquista, reforma o destrucción), no queda otro remedio que concluir que estética y Estado, estética y política, pertenecen a órdenes inconmensurables. A pesar del afán transformativo de buena parte del pensamiento y trabajo estéticos, Rancière recuerda que estamos ante una falsa afinidad, una relación presidida por equívocos fatales, radicalismos sin tracción alguna, y colisiones dolorosas y abusivas. En la trastienda de estos cortocircuitos, hallamos el siguiente dilema. En el diseño fehaciente (no-utópico) de la Modernidad capitalista, que distancia unas esferas de otras transmutando el espacio público en una torre de Babel (en realidad, un ilimitado - quasi-borgesiano mall de adquisición compulsiva con el sujeto como simple intermediario) (Habermas, 1991: 211-221), Estética y Estado gravitan en torno a ejes heterogéneos. Esta situación ofrece tres alternativas: 1) la resignación (asumir la estructuración moderna de facultades y prácticas); 2) la melancolía reaccionaria (intentar desandar el camino andado para volver a ese momento en el que arte, política y ética coincidían solidariamente); y 3) un dialéctico paso adelante (desmantelar la modernidad capitalista en favor de una organización colectiva que reagrupe esencialmente lo que el proyecto burgués desvincula).

La primera alternativa es, en mi opinión, la más realista, en donde nos encontramos de momento y de donde no parece que vayamos a salir en un futuro próximo. Su inconveniente es, sobra decirlo, el regusto abatido y quietista que deja. La segunda constituye el pasto idóneo para el rumiar de conservadores y reaccionarios. Como explica Frank Ankersmit, los primeros tratan un pasado perdido como objeto de deseo cognoscitivo (un objeto de estudio) y los segundos como un objeto a recuperar existencialmente, esto es, a reinstaurar (327). Unos historizan dicho pasado (el abismo que los separa de él ya no tiene remedio) y admiten implícitamente la derrota aunque busquen minimizarla. Los otros niegan la mayor y mantienen las espadas en alto: se ha de volver a ser lo que una vez se fue, el futuro ya está inscrito en el pasado. El hándicap de estas posturas es obvio: el vínculo con ese mundo desaparecido de la integración estético-político-moral tiene algo de desiderátum compensatorio o, en el peor de los casos, de proyección espectral. Las contiendas para la restitución de idealizados tiempos puros (religiosa, étnica o culturalmente prístinos) naufragan, en la actualidad, en contradicciones internas: en el acto mismo de preservar o rehabilitar un pretérito status quo reproducimos y enconamos (lo peor de) nuestro presente (Buck-Morss, 24-31) ${ }^{17}$.

\footnotetext{
${ }^{17} \mathrm{Mi}$ crítica no coincide con el típico rechazo liberal de todo signo de fanatismo. En primer lugar, el propio concepto de fanatismo es, como ha teorizado Alberto Toscano, bastante ambivalente, presentando efectos y facetas muy diversos según quién lo invoque y critique. (xxv-xxvi). En segundo lugar, hay un elemento de fanatismo liberal del que el propio liberalismo es a menudo muy poco consciente. Hay un fanatismo irredento, por ejemplo, de la tolerancia o la libertad individual, que tiene efectos tan destructivos como otros fanatismos en cuya crítica el liberalismo se siente bastante cómodo. Mi crítica se fija específicamente en un tipo de fanatismo nativista o autoctonista que, en términos religiosos,
} 

Antonio Gómez López-Quiñones

A la tercera alternativa la he llamado «un dialéctico paso adelante» porque identifica en las dos primeras una falta de mediaciones. La posición resignada se mimetiza con la inmanencia del presente: lo que hay es lo que hay. Por su parte, la melancólica niega sin más el ahora para restablecer motu proprio aquellas condiciones en las que la Estética compartía la misma substancia con política, ética, religión e incluso economía. Solo la iniciativa dialéctica refuta y realiza el presente, lo confronta en su totalidad y a la vez lo asume para superarlo: este es el hegeliano Aufheben o Aufhebung, que denota abolición, elevación, suspensión, cancelación y también conservación. Hay que esbozar un sine quo non de ese futuro en el que, tras las negaciones dialécticas necesarias, la estética rompe el corsé de su «régimen»e inunda el Estado (dejándose también inundar por este). Este futuro pasa por la dediferenciación de esos regímenes construidos por la Modernidad. Así se corta este nudo gordiano: la estrategia exitosa no malgasta sus energías buscando puentes entre Estética y Estado, entre los niveles políticos y estéticos, sino que disuelve esos mismos regímenes. Mientras que estos marcos autónomos existan, soñar con complementarlos mediante vasos comunicantes resulta iluso. La propia lógica moderna se decanta en la dirección inversa: creciente auto-regulación y desacoplamiento de sus ámbitos constitutivos. Esta es una de las patologías de ese proyecto ilustrado que Habermas entiende como incompleto, pero re-formulable y redimible. Procurar entrelazar lo que se aleja de acuerdo a su propia propensión encalla en las mencionadas aporías del modernismo literario y visual. El acercamiento más audaz a este problema (quizá de una ambición imposible hoy) es otro: desistir de tender lazos entre «regímenes» que no se dejan interconectar y acometer su supresión. No se trata de hacer dialogar a la estética y la política (el Estado), sino de derrocar esa misma distinción, sus respectivos estatus independientes.

$\mathrm{Y}$ con esto llegamos al meollo del tema, ese via negativa que nos permite reformular radicalmente las relaciones entre Literatura y Estado. La demolición del Estado (régimen político) lleva consigo la demolición de la Literatura (régimen estético). En la tradición marxista, ambas acontecerían en una sociedad que trasciende la organización productiva, la fragmentación laboral y el orden ideológico-jurídico del imperio burgués ${ }^{18}$. Las disquisiciones sobre la desaparición del Estado en el comunismo de Marx y Engels están dispersas en un ringlero de momentos un tanto lacónicos. Han sido muy citadas las aseveraciones de Engels en su Anti-Düring y en El origen de la familia, la propiedad privada y el Estado. En el primero, se afirma que el Estado no se abole de golpe a la manera

culturales o incluso ontológicos, busca recuperar o defender proyectos pre-modernos en plena modernidad. Con frecuencia, y de esto tenemos abundantes ejemplos recientes, estos proyectos caen en la irrelevancia o, lo que es peor, promueven situaciones en los que lo más cruel e instrumental del presente convive con versiones sádicas e hiper-violentas del pasado.

${ }^{18}$ Este es el problema de la teleología marxista, que a menudo ha sido sobredimensionado por sus críticos. Por una parte, en Marx encontramos muy pocas explicaciones y muy sucintas sobre esa sociedad futura. Marx es un pensador anti-utópico porque precisamente el socialismo utópico subrayaba el cisma burgués entre una necesaria realidad histórica y la ensoñación libre con otro lugar u otro momento. El marxismo es una filosofía de la praxis, y solo en esta y a través de esta se pueden ir articulando nuevas instancias de existencia objetiva y subjetiva. Al mismo tiempo, un grado de anticipación teleológica es casi inevitable para cualquier proyecto político que no se abandone a alguna forma de quietismo de lo menor. Quizá podríamos hablar de una teleología negativa en el marxismo en tanto que su desarrollo consiste en ir eliminando progresivamente el capitalismo hasta su superación. Esta teleología negativa no es, en cualquier caso, suficiente, porque toda negación tendría que venir acompañada de un momento positivo-constructivo, y estos momentos no pueden dejarse a la simple aleatoriedad del momento, es decir, exigen una planificación (incluso si esta es imperfecta y tentativa). 
anarquista, sino que se marchita o se diluye dialécticamente (1935: 307). En el segundo, se vaticina que el Estado acabará en «donde pertenece, en el museo de antigüedades, junto con la rueca y el hacha de bronce» (1972: 232). Estos axiomas en Engels y Marx han sido estudiados por Solomon Bloom en un artículo de 1942 que sigue funcionando, por su claridad, como referencia sobre el tema. Bloom arguye que el desvanecimiento escalonado del Estado se dará en una relación de inversa proporcionalidad con la propiedad privada (de los medios de producción), la división del trabajo y la subsiguiente acumulación capitalista (119-121).

En esta colectividad comunista, el desarrollo del individuo no se pliega a criterios de especialización y sub-división productivo-profesional, sino al florecimiento versátil de todas las capacidades humanas. Esto es lo que diferencia la «emancipación política» (formal) de la «emancipación humana» (plena) (Marx, 2000a: 64-69) y la «vuelta del hombre de la religión, la familia, el Estado, etcétera a su ser humano, i.e., social» (Marx, 2000b: 98). ¿Qué sucede en ese hipotético momento post-estatal, cuando la división capitalista del trabajo y la alienación del mismo han sucumbido? Al igual que la gestión pública de las cosas y la reproducción material de la existencia ya no actúan como sub-ocupaciones técnico-compartimentalizadas (i.e. la «política» vis-à-vis la «economía»), la creación estética también deja ser una micro-labor especializada. Todas se incorporan al discurrir diario de una asociación libre de hombre y mujeres involucrados en todo tipo de actividades sin que ninguna pertenezca a un grupo en especial. Por esto presagia Marx que, tras superar la «exclusiva concentración de talento artístico en individuos particulares» y su «supresión en la masa general $[\ldots]$ como consecuencia de la división del trabajo», no tendrá sentido referirse a «pintores»o «escultores»: «en una sociedad comunista no habrá pintores sino a lo sumo personas que pintan entre otras actividades» (2000c: 206 cursivas añadidas). Marx inserta el adverbio «a lo sumo» porque, en una sociedad emancipada, uno no pintaría o escribiría poemas para, por ejemplo, desplegar su creatividad o libertad (ausentes en las otras áreas de cohabitación social). Libertad y creatividad circularían expansivamente por todos los contornos y dimensiones de esa asociación voluntaria de hombres y mujeres. Hablar de política o arte perdería su relevancia porque no existirían como actividades privadas en las que grupos selectos realizan labores y desarrollan habilidades exclusivas. El Estado desaparece porque la faena política vuelve a y se licúa democráticamente en esa congregación de sujetos libres. La Estética desaparece porque democráticamente también es remetabolizada por esa misma colectividad. Parafraseando a Marx, no hay escritores sino personas que a lo sumo escriben.

Estos pasajes utópicos en la obra de un autor como Marx, básicamente historicista, materialista y anti-especulativo, son útiles. Fijan un punto de referencia (aunque sea a nivel analítico) respecto al que entender aspectos presentes de la ligación entre Estado y literatura. Para afianzar ese punto de referencia, así como la fructífera incredulidad que despierta, imaginemos lo siguiente (y propongo a continuación una reflexión contra-factual parecida a la que el geógrafo David Harvey bosqueja en su Espacios de esperanza (257-281)). Conjeturemos con una sociedad post-parlamentario/representativa y post-liberal en la que no hay «políticos» porque todos nos sumamos equitativamente a la gestión de 
la polis, a nuestro (auto)gobierno. Concibamos una sociedad sin clases (en el sentido más amplio y menos dogmático del término) en la que no hay «literatos» porque a todos nos concierne, a todos nos conviene y a todos nos interpela el uso literario del idioma. Un escalón más: en esta sociedad no hay «literatura» porque no se requiere de un micro-cosmos en donde sancionar una determinada utilización del talento léxico-gramatical. Las fronteras entre los distintos barrios guetificados del lenguaje, entre los autónomos «juegos del lenguaje» (8) de Wittgenstein y las micro-narrativas de Lyotard (xxiv), se desmoronan al no existir la propiedad privada y la división del trabajo. Las facultades mentales y lingǘsticas que hoy atribuimos a la Literatura desbordan esa linde divisoria y las descubrimos satisfactoriamente empleadas en lo que hoy entendemos como tareas exclusivamente políticas o económicas. En esta sociedad, la literatura (como otras esferas contemporáneas de confines precisos) no está en la Literatura, sino en su utilización permanente, mundana y ordinaria. En esta sociedad, no soñamos en y con un universo literario porque tenemos la libertad para hablar, pensar, escribir, discutir, interactuar y producir estéticamente.

Este escenario origina una fuerte impronta de irrealidad, como si nos asomásemos arbitrariamente a una sima sin fondo. Esta impronta es útil y de inmediato explicaré el porqué. De todas formas, antes de dar por bueno (sin más) este estupor, reparemos no en una fase futura con aires de ciencia-ficción, sino en épocas pre-modernas cuando no era posible distinguir entre lo que mucho después tildaríamos como Literatura, teología, liturgia religiosa, historiografía, tratado político, relato público o rito popular de esparcimiento. Al hablar del mundo lingüístico (ni siquiera textual) de la Edad Media sabemos que estas distinciones no se sostienen porque lo que hoy facturamos y consumimos como literatura o poesía estaba indisolublemente imbricado en lo que (muchos siglos después) catalogamos como política, entretenimiento callejero, mos/moris diario, doctrina cristiana o investigación histórica. El placer lírico o la «subjetividad lírica» (Schmidt, 9-12) surgía de y se diseminaba por coyunturas laborales, celebratorias, eclesiales, educativo-formativas, y cumplía además una función integradora, admonitoria, rememorativa, deontológica, etcétera. En suma, la literatura estaba dislocada, fuera de sus casillas, no existía y existía a la vez: no como la institución moderna que hoy categorizamos y etiquetamos frente a otras áreas sociales; sí como uno de los ingredientes consubstanciales a la semi-indefinición entre esas áreas.

De cualquier forma, dejemos a un lado este pasado (cuando la literatura no tenía nombre propio - o tenía varios - porque era otras muchas cosas) con el fin de confrontar el estupor que dejan los escarceos utópicos de Marx ${ }^{19}$. Si descendemos del registro teórico a un plano empírico, dicho estupor

\footnotetext{
${ }^{19}$ Aunque las reflexiones sobre Moscú tienen un elemento de idealización selectiva, lo cierto es que Walter Benjamin describe algunas realidades que dialogan directamente con el sketch utópico de Marx. Refiriéndose a la «deslumbrante experimentación» moscovita, concluye que «en esta pasión dominante hay tanto de deseo naif por las mejoras como de curiosidad y alegría lúdica ilimitadas» (106). En otro momento de claras reverberaciones utópico-marxistas, se pregunta Benjamin: «¿dónde más sería concebible que un distinguido líder militar pueda ser nombrado un día director de un gran teatro estatal?» (107). En relación a la literatura, Benjamin también menciona algo que nos hace pensar de inmediato en las predicciones de Marx: «el escritor "free-lance” debe también desaparecer. En Rusia este proceso se ha completado: el intelectual es sobre todo un funcionario, participando en los departamentos de censura, justicia, finanzas y en el trabajo que en Rusia significa poder» (120). La habilidad literaria se ha diseminado por otras muchas áreas sociales. Incluso el género teatral se usa para redimensionar y popularizar performativamente la justicia (123). Debemos tomar las reacciones de Benjamin cum grano salis. Ahora bien, es muy revelador que lo que leemos en Marx como elucubraciones a futuro, en
} 
aminora. Que la disipación del Estado coadyuve a la de la Literatura adquiere bastante verosimilitud si tenemos en cuenta que ambos surgen a la par. En concreto, la Literatura (lo que actualmente designamos de este modo) es una sub-institución que se gesta al calor de los Estados-nación modernos. Sin estos últimos, la primera habría sido imposible. Michael Gardiner afirma, por ejemplo, que «la forma disciplinar de la Literatura inglesa se funda - y ha sido constituida - en la forma de un Estado británico» (2). En la Península Ibérica, la consumación de una historia literaria (una empresa decisoria para la demarcación entre literatura y lo que no lo es) data del siglo XVIII y surge de un doble impulso estatal (Ríos-Font, 16-17). En el interior de la península, el Estado pone los medios para la nacionalización de un disímil caudal textual en un contexto de nuevas instituciones oficiales (academias, diccionarios, sociedades, bibliotecas, escuelas especializadas, juntas académicas, institutos científicos). En el exterior, los Estados se definen y se apuntalan en oposición a otros, entablando una competencia nacionalista y también «humanístico-literaria» (Hirschi, 153-155). Desde el Estado se diseñan los procedimientos, se financian los recursos, se forma a los expertos y se divulgan los resultados de la edificación de ese monumento ad majorem patriae gloriam, la Literatura, mejor dicho, nuestra literatura. Sin la locomotora de los Estados espoleando la configuración de cánones, manuales, troncos lingüísticos, periodizaciones estilísticas, listados de autores y orígenes inmemoriales, no ha lugar a hablar de literatura como hoy lo hacemos. Por supuesto, indagar en esta historia de recíproca conformación (Estado-Literatura) es mucho más fácil que desandarlo o imaginar alternativas. Por eso mismo las palabras de Marx causan estupefacción, no por su fantasiosa futilidad sino justo por lo contrario: nos conminan a encarar un fait accompli tan exitosamente consumado que su cuestionamiento desconcierta. El Estado moldea lo que discutimos y adquirimos como Literatura en una evolución típicamente moderna de deslindamiento de esferas sociales. La crisis de dicha evolución o del Estado, su derribo parcial o total, comportaría también el de la Literatura.

\section{Bio-política, Crisis, Estado}

Para cerrar este ensayo me gustaría poner sobre el tapete varias conclusiones. La primera supone una aclaración metodológica. Mis argumentos se despliegan en una longitud de onda deliberadamente teórica. Sería una necedad negar su naturaleza abstracta, conceptual en su conjunto. Dada esta tónica analítica, mi tesis no postula que las relaciones Estado-Literatura sean directamente experimentables a este nivel. Entre cómo percibimos dichas relaciones desde una óptica positivista y mis propias consideraciones hay múltiples capas intermedias. Lo que defiendo es que cuestiones como la patrimonialización de la literatura, la literatura y la ley, la literatura y la educación, o las literaturas y las fronteras son expresiones (importantes sin duda) de una trabazón de origen. En otras palabras, solo asumiendo que el Estado no puede volcarse sobre la Literatura como si esta fuese una partícula libre porque Estado y Literatura nacen juntos, estamos en condiciones de conceptualizar toda esta conversación adecuadamente. No hay una literatura que, tras un zarpazo del ogro filantrópico, quede

el teórico berlinés ya aparece como parte de un cuaderno de bitácora, un recuento de primera mano de lo presenciado en Moscú en 1926. 
marcada por las garras del Estado. Permítaseme una pedantería: la literatura no es esa vaporosa y grácil Dafne que huye del tacto apolíneo y petrificante del Estado. Ambos se sustentan simbióticamente $a b$ ovo. La segunda conclusión se desprende de la primera y tiene un cariz negativo. En mi opinión, hacer historia de la literatura a través del pujante paradigma bio-político desfigura sobremanera los términos en los que esa historia acontece.

No es mi intención azuzar ninguna polémica y no cito en consecuencia ejemplos concretos. Ahora bien, ya circulan monográficos, volúmenes colectivos y alguna revista académica que, frontal o tangencialmente, ponen su foco de atención en un corpus literario para elogiarlo bajo la fábula de un poder bio-político contra el que se insubordina y frente al que potencia intensidades alla maniera di Spinoza-Deleuze. Este giro bio-político en las Humanidades se inspira en las conferencias que Michel Foucault pronuncia en el Collège de France en 1978 y 1979. Estas fueron publicadas póstumamente y trazan una historia de la gubernamentalidad liberal desde el siglo XVIII. Quien con más éxito ha recogido el guante de Foucault ha sido el tándem italiano Esposito-Agamben. En términos muy básicos, Roberto Esposito triangula los conceptos bíos, zōé y technē para describir la bio-política como «una política en el nombre de la vida» y el bio-poder como «una vida subyugada al mandato de la política» (15). Filosóficamente, la vida de la bio-política y del bio-poder nos llega ya filtrada por una red normativa que sanciona su validez o invalidez, su conservación o destrucción.

Igual que Esposito concluye su libro Bíos considerando la thanato-política del Nacional Socialismo, Agamben abre su Homo Sacer (edición estadounidense) con un plano de Auschwitz y lo cierra con un capítulo titulado «El Campo como el "Nomos" de lo Moderno» (166). En definitiva, el Nazismo culmina el proyecto bio-político moderno (sometimiento extremo de la vida a una regulación política), del que el Estado ha sido gran adalid: «nuestra época no es nada más que el implacable y metódico intento de [...] eliminar radicalmente a la gente que es excluida» (179). Dejando a un lado los dictámenes hiperbólicos en los que a menudo incurren estos autores, lo cierto es que su planteamiento básico está dando ya sus frutos en la crítica literario-cultural. No es difícil sucumbir a su atractivo: contra instancias estatales de reglamentación y disciplina se encomia una literatura del disenso y del desorden vitalista, heterodoxo y excéntrico. En mi opinión, no es menor el hándicap de esta oposición entre el Estado (que se arroja sobre la vida como una camisa de fuerza) y una literatura díscola, proteica, proliferante y disconforme que se escapa por los intersticios de cualquier control. Este es su gran inconveniente: se magnifica y erotiza el shock puntual que provocan ciertas salidas de tono biográfico-discursivas, y simultáneamente se omite que hay «literatura» porque existen el «Estado» y su correspondiente departamentalización de campos teóricos y prácticos. Es decir, la condición de posibilidad de la literatura y de su experimentación bio-celebratoria es el Estado. La maniobra festiva de una literatura que subvierte los códigos del Estado es también el efecto de la existencia instauradora de este.

Mi tercera conclusión consiste en matizar el fatalismo que pueda inferirse del argumento anterior. No en balde, sería un error de bulto equiparar todos los tipos de literatura, todas sus posibles recepciones y todas sus reacomodaciones frente al Estado. Ahora bien, si lo que perseguimos a un 
nivel fundamental es otra Literatura, hará falta con anterioridad otro Estado. Intentaré explicitar esta idea de la manera más precisa posible. Uno puede alterar la dicción literaria o incluso la distribución y el uso de un texto-objeto. En la vanguardia tenemos ilustres ejemplos de una experimentación formal llevada hasta el precipicio de lo indecible, la página en blanco y el tomo en tanto que obra pictórica, escultórica e incluso performativa. Al mismo tiempo, esta transgresión de códigos expresivos, formatos genéricos y expectativas lectoras nunca alteraron el tablero de una modernidad capitalista donde estética, política, moral, ciencia y religión se des-acompasan. Este es el límite infranqueable de toda indagación estética por muy violenta que sea. Esto explica la normalización de la energía iconoclasta del alto modernismo, su anexión a la historia de la literatura como un capítulo más, su comercialización y/o su eventual canonización conservadora. El punto muerto de esta estrategia es evidente: uno no cambia una realidad histórica - el Estado o el régimen de lo político - desde y $a$ través de la literatura y la estética.

Esta intentona (ya lo sabemos) termina en las antípodas del propósito inicial: son esa realidad histórica, el Estado y el régimen de lo político los que re-asimilan cualquier prodigio literario disonante. Como bien observara Octavio Paz en Los hijos del limo, de la ruptura de la tradición se pasa en muy poco tiempo a la «tradición de la ruptura» y a su museificación en los gabinetes de trastos venerables (1987: 24). Digámoslo en positivo: si se ansían una literatura fuera de sí, expandir lo que hoy hace y dice, hacer saltar los diques que constriñen su riqueza lingüística y la circulación de dicha riqueza, se precisa con anterioridad otra estratificación de las ramas del conocimiento y la acción. Sin duda, la estética tendrá su papel activo en este proceso, pero no será su motor. No se revoluciona un proceder estético para transfigurar un estado de cosas político-material (un idealismo de las artes en toda regla), sino que al revolucionar esa realidad de inmediato se le abren a la estética potencialidades inauditas. Obviamente, este cometido tiene un calado mucho más profundo que el simple afán voluntarista del hallazgo léxico-gramatical, la fortuna compositiva o el manifiesto programático en pos de un arte nuevo (uno más). Para una literatura no confinada en los anaqueles de bibliotecas especializadas, en las mesas de novedades de grandes shopping centers, en cursos académicos (cada vez menos y menos concurridos), en cenáculos para iniciados y devotos, e instituciones que limpian, fijan y dan esplendor, en definitiva, para una literatura no ensimismada en un bucle centrípeto de distinción especializada, hay que romper (con) el Estado. Su función es la de una clave de bóveda en una semiesfera arquitectónica: si esta se resquebraja, todas las fuerzas que en ella convergen también caen, abriendo innumerables canales para nuevas distribuciones y combinaciones de todas nuestras destrezas sociales (incluida la literaria).

Una última conclusión: circula un rumor sobre la «ulterior desintegración de las naciones-estado y de las culturas nacionales» a manos de lo que algunos sociólogos llamaron la globalización (Waters, 106). La división internacional del trabajo, la movilidad de fábricas y plantas de montaje, la desterritorialización del capital financiero, el estatus flotante de las transnacionales, el flujo de mercancías, las oleadas migratorias y un homogéneo multiculturalismo ad hoc estarían a punto de dejar a los viejos Estados westfalianos en una posición supernumeraria, subsidiaria. Sin entrar en los méritos y 
desventajas del concepto mismo de globalización, la escueta pero convulsa historia del siglo XXI desmiente por completo este rumor. El Estado varía parcialmente de perfil, pero resulta un actor tan imprescindible como lo era hace 100 o 150 años (probablemente más). Por una parte, desde 2001 los Estados ejecutan complejos planes de seguridad en los que se emplean ataques bélicos, inteligencia y contra-inteligencia, supervisión de fronteras y colectivos étnicos, leyes excepcionales y colaboración entre gobiernos al margen de la legislación internacional. Con unos medios técnicos sin precedentes y un armamento de sofisticación futurista, los Estados potencian su monopolio de la violencia para hacer frente a la marea de conflictos que se inaugura con la segunda guerra de Irak en 2003. En un acertado juego de palabras, Scott Poyting y David Whyte describen este status quo como «la guerra del terror como terror», en la que «hay siempre una solidaridad escondida entre el terrorismo de estado y las técnicas que los estados usan bajo la rúbrica "guerra contra el terror"» (1).

Por otra parte, y partir de la Gran Recesión en 2008, la fantasía de un mundo con Estados prácticamente nominales, simples testigos de la milagrosa mano invisible del Mercado, pierde la credibilidad que (quizá) alguna vez tuvo entre los lectores desprevenidos de Adam Smith. En mitad de un tsunami de desempleo, bajadas salariales, desahucios, cortes energéticos, ajuste de deuda pública, recortes de las ya menguadas prestaciones sociales y reformas labores regresivas, los Estados tienen que emplearse a fondo para contener una amplia corriente de descontento. Es factible que estemos, en el decir de Antonio Gramsci, ante una «revolución-restauración» o una «revolución pasiva» (372), ante tumultos, sufrimientos y desequilibrios sociales que se instrumentalizan para frenar metamorfosis agudas. Este gatopardismo que se instaura en tantos países europeos («que todo cambie para que todo siga como está») sería impracticable sin los Estados. Con un sistema capitalista que entra en barrena, las estructuras estatales ideológicas, asistenciales y represivas han tenido que funcionar a toda máquina. Ha sido este andamiaje estatal, con su presencia sustentadora y con sus ausencias estrepitosas, el que para bien y para mal ha mantenido un mínimo de orden en mitad de la tormenta perfecta (hundimiento bancario, quiebra del contrato social de posguerra, crisis humanitarias, guerras sin punto y final, y protestas sociales de Madrid a Buenos Aires, de Nueva York a Santiago de Chile, de Sao Paulo a El Cairo). No es azaroso que, en esta nueva edad de oro de los Estados, el pensamiento de Carl Schmitt sobre la decisión y el poder soberanos suscitase tanto interés (Meierhenrich y Simons, 4-5).

De estos largos años de afán guerrero y dislocación económica, que han exigido una intimidad obscena entre Estados y mercados para mantener a flote a estos últimos, el régimen literario y la industria del libro no han salido indemnes. Este sería el motivo de otro ensayo, pero valga como broche final uno de esos secretos a voces en la escena editorial: la desaparición de ayudas y previos tratamientos fiscales ha puesto contra las cuerdas a un sector ya desbaratado por la crisis. El Estado no solo selecciona y promueve a unos autores, los trans-nacionaliza y exporta, subvenciona traducciones y ferias del libro, sino que además tiene a las empresas editoras (muy quebradizas de por sí o precarizadas por el bajón de ventas) en vilo. Por supuesto, si hablamos del libro académico o de géneros minoritarios, el dictamen tan solo empeora: sin alguna clase de arbitraje estatal, este boscaje 
bajo de pequeñas tiradas y editoriales caseras se marchitaría rápidamente. En resumen, no hay mercados sin Estados que completen un sinfín de funciones para que los primeros funcionen (disfuncionalmente). Tampoco hay mercado de libro ni mercantilización de la literatura sin Estados que colaboren proactivamente mediante legislaciones especiales, acuerdos comerciales, organismos publicitarios y rituales de canonización ${ }^{20}$. Los últimos tres lustros ponen en la palestra toda esa fanfarria de la sociedad civil autosuficiente y de un capitalismo privatizador que eficazmente provee lo que el Estado no aporta o aporta mal. Expresiones como literatura post-estatal son significantes vacíos: el régimen estético y la institución de la literatura nacen con el Estado y como efecto del fraccionamiento de lo social en burbujas con lógicas propias. Sacar a la literatura de su celda de oro, desatar nuevos hábitos estéticos, y recomponer las parcelas y funciones atomizadas del lenguaje no depende de hallazgos geniales ni de poéticas rompedoras. Para que la literatura sea algo disto de lo que hoy es (una suerte de urbanización vallada, subsumida en el mercado bajo el tutelaje ulterior del Estado), aguardan por delante desafíos políticos de máxima dificultad a los que aún no estamos en condiciones de hacer frente. Ante la perplejidad de un reto que pareciera imbatible, quizá tan solo necesitemos por ahora resistir la tentación que Samuel Beckett cifrara en Molloy: "en los primeros estadios, es tan agradable saber a donde se dirige uno. Casi te libera del deseo de ir allí" (15).

\section{Bibliografía}

Agamben, G. (1995): Homo Socer: Sovereign Power and Bare Life. Trad. Daniel Heller-Roazen. Stanford, Stanford University Press, 1998.

ANDERSON, P. (2006): The Origins of Postmodernity. London, Verso.

ANKERSMit, F. (2005): Sublime Historical Experience. Stanford, Standord University Press.

BECKETT, S. (2006): Novels. Volume II. New York, Grove.

Benjamin, W. (1935): «Moscow», en P. DEMETZ, ed., Reflections. Essays, Aphorisms, Autrobiographical Writings. New York, Schocken, 2007, pp. 97-130.

(1936): «The Work of Art in the Age of Mechanical Reproduction», en Illuminations. New York, Schocken, 1968.

BILlingS, J. (2014): Genealogy of the Tragic: Greek and Tragedy and German Philosophy. Princeton, Princeton University Press.

\footnotetext{
${ }^{20}$ Estas afirmaciones no implican la negación de disciplinas u objetos de estudio como la literatura comparada o la literatura mundial (world literature). Una de las figuras que más ha hecho por promover la segunda, David Damrosch, explica que esta no es simplemente un conjunto de texto y (mucho menos) la totalidad de textos que se publican en el orbe (4). La literatura mundial es un sistema de circulación e incluso de producción literaria (5) en el que la historia y situación geopolíticas de los Estados-nación, de los Estados plurinacionales y de las naciones sin Estado tienen un efecto decisorio en cómo una literatura y unos textos específicos se insertan (o no) en dicha circulación y producción. La política de selección estética, traducciones, deseos de exotismo y autenticidad, ausencias sorprendentes y modas pasajeras en ese fluido corpus que llamamos literatura mundial no se deja explicar si no es en relación al desarrollo y fortuna de los Estados-nación. Es más, como bien afirma Damrosch siguiendo el marco de los «sistemas-mundo» de Immanuel Wallerstein, no podemos hablar con propiedad de una literatura mundial sino de varias literaturas mundiales que, según hayan sido construidas en China, Brasil o la India, no coinciden en sus límites y contenido (15-22). En conclusión, construir marcos de entendimiento supra-estatal de la literatura exige tener en cuenta la presencia, historia y suerte de cada Estado en relación a otros (modernidades tardías, alter-modernidades, imperios, guerras, (post-)colonialidad, etcétera).
} 
30 Tropelías. Revista de Teoría de la Literatura y Literatura Comparada, número extraordinario 4 (2018) Antonio Gómez López-Quiñones

Bloom, S. (1946): «The "Withering Away" of the State», Journal of the History of Ideas, 7/1, pp. 113-121.

Bosteels, B. (2011): The Actuality of Communism. London, Verso.

Botero, G. (1589): The Reason of State. Trad. Robert Bireley. Cambridge, Cambridge University Press, 2017.

Buck-Morss, S. (2003). Thinking Past Terror. Islamism and Critical Theory on the Left. London, Verso.

Calvino, I. (1988): Six Memos for the Next Millennium. Trad. Geoffrey Brock. Boston, First Mariner, 2016.

CAstro Oury, E. (1995): La Guerra de la Independencia española. Madrid, Akal.

Damrosch, D. (2003): «Goethe Coins a Phrase», en D. DAmrosch, ed., What is World Literature?

Princeton (NJ), Princeton University Press, pp. 1-36.

EAgLETON, T. (2000): The Idea of Culture. Oxford, Blackwell. (1990): The Ideology of Aesthetic. Oxford, Blackwell.

Engels, F. (1884): The Origin of the Family, Private Property and the State. Trad. Alec West. New York, International Publishers, 1972.

- (1878): Herr Eugen Dühring's Revolution in Science. Trad. Emile Burns. New York, International Publishers, 1935.

ESCOHOTADO, A. (2008): Los enemigos del comercio I. Una historia moral de la propiedad. Madrid, Espasa.

Esposito, R. (2004): Bíos: Biopolitics and Philosophy. Trad. Timothy Campbell. Minneapolis, University of Minnesota Press, 2008.

FAWCETT, E. (2014): Liberalism: The Life of an Idea. Princeton, Princeton University Press.

FRIEDMAN, M. (1993): Why the Government Is the Problem. Stanford, Stanford University Press, 2001.

FRIEDMAN, M. - FriedMAN, R. (1980): Free to Choose. New York, Harvest, 1990.

Foucault, M. (2004): The Birth of Biopolitics. Lectures at the Collège de France, 1978-1979. Trad. Graham Burchell. New York, Palgrave, 2008.

GARDINER, M. (2013): The Constitution of English Literature. The State, the Nation, and the Canon. London, Bloomsbury.

Glendinning, N. (2008): Arte, ideología y originalidad en la obra de Goya. Trad. Marta García Gato. Salamanca, Universidad de Salamanca.

GotTlieb, E. (2001): Dystopian Fictions East and West. Universe of Terror and Trial. Kingston, McGill-Queen University Press.

GramsCI, A. (1975): Prison Notebooks. Volume III. Trad. Joseph Buttigieg. New York, Columbia University Press, 2007.

GuYer, P. (2008): «Marcuse and Classical Aesthetics», Revue Internationale de Philosophie, 4/246, pp. 349-365. 
Habermas, J. (1985): The Philosophical Discourse of Modernity. Trad. Frederick G. Lawrence. Cambridge (MA), MIT Press, 2000.

(1962): The Structural Transformation of the Public Sphere. An Inquiry into a Category of Bourgeois Society. Trad. de Thomas Burger. Cambridge (MA), MIT Press, 1991.

HARVEY, D. (2000): Spaces of Hope. Berkeley, University of California Press.

HAYEK, F. (1944): The Road to Serfdom. New York, Routledge, 2001.

HIRSCHI, H. (2012): The Origins of Nationalism: An Alternative History from Ancient Rome to Early Modern Germany. Cambridge, Cambridge University Press.

HobBes, T. (1651): Leviathan. New York, Penguin, 1985.

Honneth, A. (1990): The Fragmented World of the Social: Essays in Social and Political Philosophy. Albany (NY), State University of New York Press, 1995.

KANT, I. (1790): Critique of Judgment. Trad. J. H. Bernard. New York, Barnes \& Nobles, 2005.

LipoVETSKy, G. - SERROY, J. (2013): La estetización del mundo. Vivir en la época del capitalismo artístico. Trad. Antonio Prometeo Moya. Barcelona, Anagrama, 2015.

LöwY, M. (2001): Romanticism Against the Tide of Modernity. Trad. Catherine Porter. Durham (NC), Duke University Press, 2001.

LyOtARD, J.-F. (1979): The Postmodern Condition: A Report on Knowledge. Trad. Geoff Bennington y Brian Massumi. Minneapolis, University of Minnesota Press, 1984.

Marcuse, H. (1969). An Essay on Liberation. Boston, Beacon.

MarX, K. (1843): «On the Jewish Question», en D. McLellan, ed., Karl Marx. Selected Writings. Oxford, Oxford University Press, 2000, pp. 46-70.

(1932): «Economic and Philosophical Manuscripts», en D. MCLELlan, ed., Karl Marx. Selected Writings. Oxford, Oxford University Press, 2000, pp. 83-121.

(1844): «The German Ideology», en D. MCLELlan, ed., Karl Marx. Selected Writings. Oxford, Oxford University Press, 2000, pp. 175-211

McLaughlin, P. (2007): Anarchism and Authority: A Philosophical Introduction to Classical Anarchism. London, Routledge.

MEIERHENRICH, J. - SiMONS, O. (2016): “"A Fanatic of Order in an Epoch of Confusing Turmoil”: The Political, Legal, and Cultural Thought of Carl Schmitt», en J. MEIERHENRICH y O. SimONS, eds., The Oxford Handbook of Carl Schmitt. Oxford, Oxford University Press, pp. 3-71.

Moss, L. (2005). «Private property anarchism: an American variant», en E. STRINGHAM, ed., Anarchy, State and Public Choice. Cheltenham (UK), Edward Elgar, pp. 123-152.

NiETZSCHE, F. (1891): Thus Spoke Zarathustra. Trad. Thomas Common. New York, Barnes \& Nobles, 2012.

O'ConNor, Brian. (2014): «Play, Idleness and the Problem of Necessity in Schiller and Marcuse», British Journal for the History of Philosophy, 22/6, pp. 1095-1117.

PAZ, O. (1987): Los hijos del limo, Barcelona, Seix-Barral. (1979): El ogro filantrópico. Barcelona, Seix-Barral. 
Tropelías. Revista de Teoría de la Literatura y Literatura Comparada, número extraordinario 4 (2018) Antonio Gómez López-Quiñones

Poyting, S. - WhYTe, D. (2012): «Introduction: counter-terrorism and terrorist state», en S. PoYTING y D. WhYTE, eds., Counter-Terrorism and State Political Violence. London, Routledge, pp. 111.

PIPPIN, R. (1999): Modernism as a Philosophical Problem. On the Dissatisfaction of European High Culture. Oxford, Blackwell, $2^{\mathrm{a}}$ ed., 1999.

RANCIÈRE, J. (2000): The Politics of Aesthetics. Trad. Gabriel Rockhill. New York, Continuum, 2004.

RíOS-FONT, W. (2009): «Literary history and canon formation», en D. GIES, ed., The Cambridge History of Spanish Literature. Cambridge, Cambridge University Press, pp. 1-14.

Rousseau, J.-J. (1997): The Social Contract and other Later Political Writings. Trad. Victor Gourevitch. Cambridge, Cambridge University Press.

SARTwell, C. (2008): Against the State. An Introduction to Anarchist Political Theory. Albany (NY), State University of New York Press.

SCHILlER, F. (1795): On the Aesthetic Education of Man. Trad. Reginald Snell. New York, Dover, 2004.

SCHMIDT, D. (2005): Lyrical and Ethical Subject. Essays on the Periphery of the World, Freedom, and History. Albany (NY), State University of New York Press.

SchwartzWALD, J. (2017): The Rise of the Nation-State in Europe: Absolutism, Enlightenment and Revolution, 1603-1815. Jefferson (NC), McFarland.

Toscano, A. (2010): Fanaticism. On the Uses of an Idea. London, Verso.

WARren, J. (2011): The Practical Anarchist. Writings of Josiah Warren. New York, Fordham University Press.

Wittgenstein, L. (1953): Philosophical Investigations. Trad. G. E. M. Anscombe, P. M. S. Hacker y J. Schulte. Malden (MA), Wiley-Blackwell, 2009.

WATERS, M. (1995): Globalization. New York, Routledge, $2^{\text {a }}$ ed., 2001.

ŽIŽEK, S. (2014): Event. A Philosophical Journey through a Concept. New York, Penguin. 